Original

\title{
Evaluation of a Nitric Acid-based Partial-digestion Method for Selective Determination of Inorganic Arsenic in Rice
}

(Received January 18, 2008)

\author{
Megumi Hamano-Nagaoka ${ }^{1, *}$, Tsutomu Nishimura ${ }^{2}$, Rieko Matsuda ${ }^{1}$ \\ and Tamio MaITANi ${ }^{1}$ \\ ${ }^{1}$ National Institute of Health Sciences: 1-18-1 Kamiyoga, Setagaya-ku, Tokyo 158-8501, Japan; \\ ${ }^{2}$ Japan Food Research Laboratories: 11-10 Nagayama 6-chome, Tama-shi, \\ Tokyo 206-0025, Japan; * Corresponding author
}

\begin{abstract}
Arsenic (As) uptake in human occurs via the food chain mainly. The Joint FAO/WHO Expert Committee on Food Additives has established the provisional tolerable weekly intake level for As as an inorganic As (iAs) value, because iAs in food is much more toxic than organic As. In this study, we studied an acid based partial-digestion method for the complete extraction of arsenicals from rice. HPLC/ICP-MS was used to determine the concentration of iAs selectively. The conditions adopted to extract arsenicals from a $0.5 \mathrm{~g}$ of finely ground rice sample were addition of $2 \mathrm{~mL}$ of $0.15 \mathrm{~mol} / \mathrm{L}$ nitric acid and heating at $80^{\circ} \mathrm{C}$ for $2 \mathrm{hr}$. The LOD and LOQ for iAs were 0.0024 and $0.0079 \mathrm{mg} / \mathrm{kg}$ dry weight, respectively. Recovery studies showed good accuracy. When the method was applied to ten short-grain brown rice samples, the iAs concentrations were 0.108$0.227 \mathrm{mg} / \mathrm{kg}$ dry weight and the total As concentrations were $0.118-0.260 \mathrm{mg} / \mathrm{kg}$ dry weight. Although dimethylarsinic acid was also detected in most samples, the percentage of iAs content in total As content was 62.2-96.3\%. Thus, iAs was the principal As species in the short-grain brown rice samples tested.
\end{abstract}

Key words: arsenic; inorganic arsenic; rice; HPLC/ICP-MS; partial digestion; nitric acid

\section{Introduction}

Uptake of arsenic (As) in human mainly occurs via the food chain, and, in special cases, also via occupational exposure ${ }^{1)-3)}$. Since the inorganic arsenic (iAs) in food is much more toxic than the organic $\mathrm{As}^{4), 5)}$, the JECFA (the Joint FAO/WHO Expert Committee on Food Additives) has established a provisional tolerable weekly intake (PTWI) level as an value $(0.015 \mathrm{mg} / \mathrm{kg} \mathrm{bw} /$ week).

The major amount of ingested As comes from fish, shellfish, and seaweed, in which most of As compounds are fortunately non-toxic arsenobetaine (AB) or $\operatorname{arsenosugars}^{6)}$. In contrast to the seafoods, the rice plant bio-accumulates more toxic iAs species, arsenate and arsenite ${ }^{7), 8)}$. Therefore, the contribution of rice to the total intake of iAs may be considerably high. For example, when a person weighing $50 \mathrm{~kg}$ consumes 150 $\mathrm{g}$ of brown rice containing As at the level of $0.16 \mathrm{mg} / \mathrm{kg}$ dry weight*1 per day, the As intake is calculated to be $0.0034 \mathrm{mg}$ total $\mathrm{As} / \mathrm{kg} \mathrm{bw} /$ week. If all As compounds in rice are present as iAs, this intake corresponds to $23 \%$ of the PTWI value. Consequently, the speciation of As in rice is very important from the viewpoint of risk-assessment of As for the Japanese population.

\footnotetext{
*1 http://www.maff.go.jp/syohi_anzen/profiles/arsenic.pdf Annex.
}

One of the requirements for assessing the risk of consuming food containing $\mathrm{As}$ is a quantitative or nearly quantitative method for determining arsenicals without transformation of the original chemical species. The main problems encountered have been low recovery and oxidation/reduction between As(III) and $\mathrm{As}(\mathrm{V})^{9}$. Quantitative extraction is also essential, because the extraction procedure may selectively extract non-toxic species from food and/or leave toxic species unextracted within the solid matrix. Arsenic speciation demands mild extraction so as to maintain species integrity. Although speciation studies have been widely performed for As in marine products, the speciation studies of As in rice are not numerous. In those studies, methanol, water, a methanol/water mixture, and trifluoroacetic acid (TFA) have been used as solvents to extract As species from rice samples ${ }^{10)-15)}$. Although quantitative extraction of As from some foods has been achieved with these solvents, it has been difficult to achieve thorough extraction from rice samples. Attempts to utilize an accelerated solvent extraction technique ${ }^{1,10,16,17)}$ or enzymatic ultrasonic probe ${ }^{18)}$ have been reported for rice, but As extraction from rice samples remains difficult ${ }^{6), 19)}$.

In our preceding report, the nitric acid-based partialdigestion method was assessed as a mean of achieving complete As extraction from hijiki samples ${ }^{20)}$. In this paper, therefore, the partial acid-digestion method was 
applied for rice, to completely extract iAs from rice samples. Nitric acid was used under conditions such that organic As species were not converted to iAs. This method was coupled with HPLC/ICP-MS to determine As species including iAs separately.

\section{Materials and Methods}

\section{Reagents}

Sodium arsenate $\left(\mathrm{Na}_{2} \mathrm{HAsO}_{4}\right)$, sodium arsenite $\left(\mathrm{NaAsO}_{2}\right)$, monomethylarsonic acid (MMA), dimethylarsinic acid (DMA), and trimethylarsine oxide (TMAO) were purchased from Wako Pure Chemical Industries, Ltd. (Osaka, Japan). AB was obtained from Trichemical Laboratory (Yamanashi, Japan). Ultra-pure analytical grade nitric acid (68\%) and tetramethylammonium hydroxide (TMAH, 20\%) (TAMAPURE-AA-100) were purchased from Tama Chemical Industry (Kanagawa, Japan). Other chemicals were of reagent grade or of the highest grade available commercially. All laboratory glass ware and plastic ware used were immersed in approximately $2 \mathrm{~mol} / \mathrm{L} \mathrm{HNO}_{3}$ at least overnight and rinsed with ultra-pure water prepared with a Milli-Q SP Reagent Water System (Millipore, Bedford, MA) to avoid contamination with various ions. Water of this grade was used throughout the experiment.

\section{Rice}

Short-grain brown rice samples were obtained from supermarkets in the Tokyo Metropolitan area and by mail order in Japan. Before analysis, all samples were carefully ground into fine powders with a grinder (Micron Milcer, Iwatani Int. Corp., Tokyo, Japan) for 1 min four times at intervals of 3 min.

\section{Extraction procedure for rice}

A ground rice powder sample (0.5 g dry weight) was mixed with $2 \mathrm{~mL}$ of nitric acid $(0.15 \mathrm{~mol} / \mathrm{L})$ in a $10 \mathrm{~mL}$ capped high-density polyethylene (HDPE) centrifuge tube, and the mixture was heated on an aluminum heat block at $80^{\circ} \mathrm{C}$ for $2 \mathrm{hr}$. The solution obtained was diluted to $10 \mathrm{~mL}$ with water and passed through a 0.45 $\mu \mathrm{m}$ filter prior to analysis.

\section{Determination of $i$ As by HPLC/ICP-MS}

The HPLC apparatus (Agilent 1200 Series, Agilent Technologies, Tokyo, Japan) was equipped with an HPLC column (CAPCELL PAK $\mathrm{C}_{18} \mathrm{MG}, 4.6 \mathrm{~mm}$ i.d. $\times$ $250 \mathrm{~mm}$, Shiseido Ltd., Tokyo, Japan). The solvent, a solution ( $\mathrm{pH}$ 3.0) composed of $10 \mathrm{mmol} / \mathrm{L}$ sodium 1butanesulfonate, $4 \mathrm{mmol} / \mathrm{L}$ TMAH, $4 \mathrm{mmol} / \mathrm{L}$ malonic acid, and $0.05 \%$ methanol, was used for isocratic elution at a flow rate of $0.75 \mathrm{~mL} / \mathrm{min}$. The sample solution $(20$ $\mu \mathrm{L})$ was loaded onto the column and eluted at room temperature. In this study, the retention time did not change at this temperature.

The Agilent 7500 ce ICP-MS system (Agilent Technologies) was used. The analytical conditions were: RF power, $1.6 \mathrm{~kW}$; plasma gas, $15 \mathrm{~L} / \mathrm{min}$; carrier gas, 0.70 L/min; auxiliary gas, $0.90 \mathrm{~L} / \mathrm{min}$; makeup gas, $0.43 \mathrm{~L} /$ min. Signal ion monitoring at $\mathrm{m} / \mathrm{z} 75$ and a sampling rate of $1 \mathrm{~Hz}$ were used to collect the chromatographic data.

\section{Determination of total As}

A finely ground powdered rice sample $(0.1-1 \mathrm{~g}$ dry weight) was weighed, transferred to a Kjeldahl flask, and heated with nitric acid $(10 \mathrm{~mL})$. Then, $5 \mathrm{~mL}$ of sulfuric acid was added to the flask, and heating was continued until white fumes of sulfuric acid appeared. Hydrogen peroxide (2 mL, 30\%) was added to the flask, and heating was continued. After cooling, $15 \mathrm{~mL}$ of saturated ammonium oxalate solution was added to the flask, and heating was continued. A $5 \mathrm{~mL}$ volume of potassium iodide solution (40\%) was added, and after the solution had been allowed to stand for $30 \mathrm{~min}$, a 5 $\mathrm{mL}$ volume of ascorbic acid solution (10\%) was added. Finally, water was added to adjust the volume to 50 $\mathrm{mL}$. The total amount of As was measured by hydride generation-atomic absorption spectrometry (HG-AAS) (Varian Spectra AA220 with VGA-77, Varian Japan, Tokyo).

\section{Extraction efficiency}

Extraction efficiency (extraction [\%]) was evaluated as the ratio of extracted As content to total As content. The As concentration of each extract solution was determined by ICP-MS after dilution with $0.1 \mathrm{~mol} / \mathrm{L}$ nitric acid solution, unless otherwise noted.

\section{Results and Discussion}

Speciation analysis of standard arsenicals and a partially digested rice sample by HPLC/ICP-MS

The HPLC/ICP-MS system was used to analyze six standard As compounds, i.e., arsenate, arsenite, MMA, DMA, AB, and TMAO. The concentration of each standard was $5 \mathrm{ng}$ As/mL. As shown in Fig. 1, they were separately detected within $10 \mathrm{~min}$.

Figure 2 shows typical HPLC/ICP-MS chromatograms for two rice samples treated according to the established partial acid-digestion method (see below). The samples shown in Figs. 2(a) and 2(b) are representatives of samples containing a low concentration (total As: $0.04 \mathrm{mg} / \mathrm{kg}$ dry weight) and high concentration

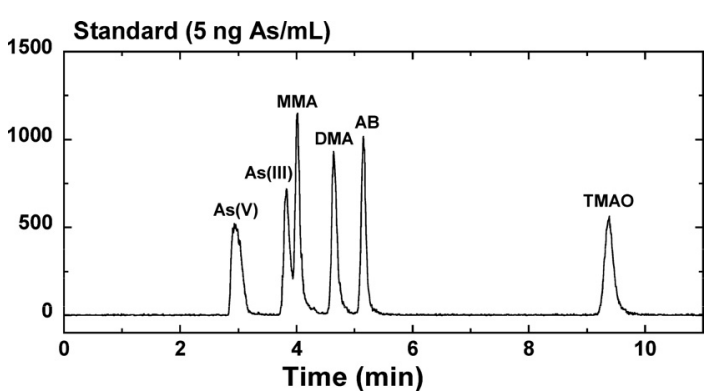

Fig. 1. HPLC/ICP-MS chromatogram of six standard As compounds

Sample injection volume, $20 \mu \mathrm{L}$; concentration of each standard As compound, $5 \mathrm{ng}$ As/mL. 

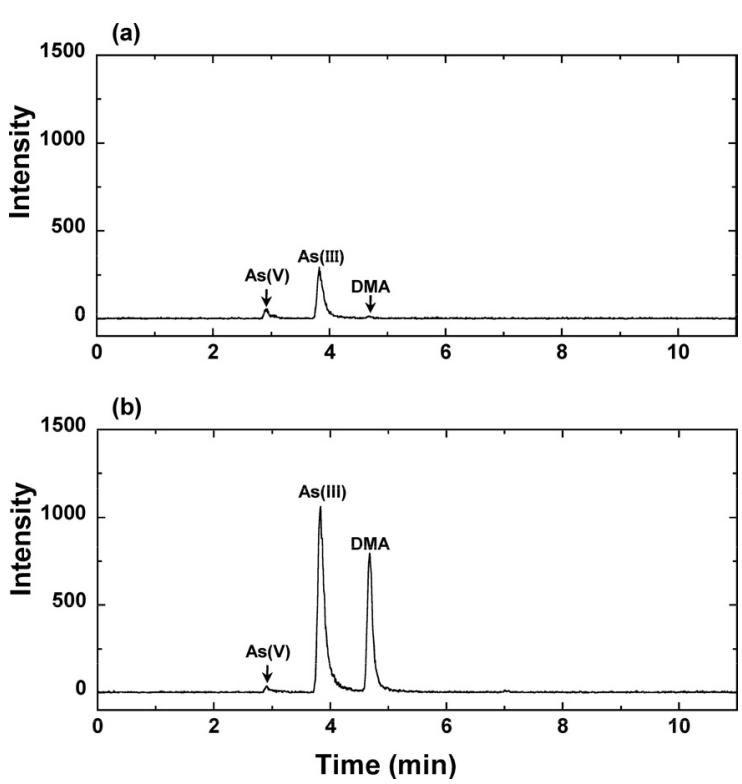

Fig. 2. HPLC/ICP-MS chromatograms for partially aciddigested rice samples

Each powdered rice sample ( $0.5 \mathrm{~g}$ dry weight) was mixed with $2 \mathrm{~mL}$ of $0.15 \mathrm{~mol} / \mathrm{L}$ nitric acid, and the mixture was heated at $80^{\circ} \mathrm{C}$ for $2 \mathrm{hr}$. The total As concentrations of the samples (a) and (b) were determined to be $0.04 \mathrm{mg} / \mathrm{kg}$ dry weight and 0.26 $\mathrm{mg} / \mathrm{kg}$ dry weight, respectively.

(total As: $0.26 \mathrm{mg} / \mathrm{kg}$ dry weight) of total As, respectively. MMA was not detected in either sample, but DMA was detected.

Concentration of nitric acid as extraction solution and extraction time

Our preceding study on hijiki samples ${ }^{20)}$ suggested that organic As species were not converted to iAs at $80^{\circ} \mathrm{C}$ and that complete extraction of As was possible by selecting optimal extraction conditions. Accordingly, a temperature of $80^{\circ} \mathrm{C}$ was also adopted in this study, and several factors were optimized as described below.

First, various acid concentrations were tested to identify the lowest nitric acid concentration that could be used without reducing the extraction efficiency. The results are shown in Table 1-1. A powdered rice sample ( $0.5 \mathrm{~g}$ dry weight) was mixed with $2 \mathrm{~mL}$ of $0.075,0.10$, $0.15,0.30$, and $1.0 \mathrm{~mol} / \mathrm{L}$ nitric acid solutions, and 2.0 $\mathrm{mol} / \mathrm{L}$ trifluoroacetic acid (TFA) in $10 \mathrm{~mL}$ capped HDPE centrifuge tubes, and the solutions were heated for $2 \mathrm{hr}$ at $80^{\circ} \mathrm{C}$. The iAs concentration and extraction efficiency were almost the same at the $0.10 \mathrm{~mol} / \mathrm{L}$ concentration and above. The DMA concentration did not increase at the higher nitric acid concentrations. Since the $\mathrm{pH}$ of the solution for analysis was $2-3$ in the case of $0.15 \mathrm{~mol} / \mathrm{L}$ nitric acid and adjustment of the $\mathrm{pH}$ was unnecessary, the $0.15 \mathrm{~mol} / \mathrm{L}$ concentration was adopted.

Addition of $2.0 \mathrm{~mol} / \mathrm{L} \mathrm{TFA}$ and heating at $100^{\circ} \mathrm{C}$ for 6 hr had been adopted to extract As from rice ${ }^{17)}$, whereas in our study the sample was treated with $2.0 \mathrm{~mol} / \mathrm{L}$ TFA and heated at $80^{\circ} \mathrm{C}$ for $2 \mathrm{hr}$. Black insoluble matter remained after the TFA treatment. Moreover, compared to the nitric acid treatment, the As(III) and $\mathrm{As}(\mathrm{V})$ concentrations were higher and lower, respectively. Furthermore, the $\mathrm{pH}$ of the solutions for analysis was 1 . Therefore, TFA was not used in this study.

Next, the extraction time was varied (Table 1-2). A milled rice powder sample (0.5 g dry weight) was mixed with $2 \mathrm{~mL}$ of $0.15 \mathrm{~mol} / \mathrm{L}$ nitric acid solution in a $10 \mathrm{~mL}$ capped HDPE centrifuge tube and heated for 0.5, 1, 2, 4, 6 , or $8 \mathrm{hr}$ at $80^{\circ} \mathrm{C}$. Since the extraction efficiency (\%) of As was almost the same from $1 \mathrm{hr}$ to $4 \mathrm{hr}$, the extraction time was fixed on $2 \mathrm{hr}$.

Nitric acid is generally regarded as an oxidative acid. However, As(III) was detected even in the case of 1.0 $\mathrm{mol} / \mathrm{L}$ nitric acid. This might suggest the presence of reductive compound(s) in brown rice.

Based on the results described above, a $0.15 \mathrm{~mol} / \mathrm{L}$ nitric acid concentration and $2 \mathrm{hr}$ extraction time were adopted.

\section{Method validation}

The method was validated in terms of linearity, limit of detection (LOD), limit of quantification (LOQ), precision, and accuracy.

Table 1-1. Effect of nitric acid concentration on extraction efficiency

\begin{tabular}{|c|c|c|c|c|c|c|c|}
\hline \multirow{2}{*}{ Extraction solution } & \multicolumn{6}{|c|}{ Concentration (mg/kg dry weight) } & \multirow{2}{*}{$\begin{array}{c}\text { Extraction }^{2)} \\
(\%)\end{array}$} \\
\hline & $\operatorname{As}(\mathrm{V})$ & $\mathrm{As}(\mathrm{III})$ & $\mathrm{iAs}(\mathrm{As}(\mathrm{V})+\mathrm{As}(\mathrm{III}))$ & MMA & DMA & Total As extracted ${ }^{1)}$ & \\
\hline $0.075 \mathrm{~mol} / \mathrm{L} \mathrm{HNO}_{3}$ & N.D. & 0.079 & 0.079 & N.D. & 0.013 & 0.120 & 87.6 \\
\hline $0.10 \mathrm{~mol} / \mathrm{L} \mathrm{HNO}_{3}$ & 0.013 & 0.106 & 0.119 & N.D. & 0.022 & 0.127 & 92.7 \\
\hline $0.15 \mathrm{~mol} / \mathrm{L} \mathrm{HNO}_{3}$ & 0.026 & 0.105 & 0.120 & N.D. & 0.025 & 0.129 & 94.2 \\
\hline $0.30 \mathrm{~mol} / \mathrm{L} \mathrm{HNO}_{3}$ & 0.031 & 0.091 & 0.122 & N.D. & 0.026 & 0.126 & 92.0 \\
\hline $1.0 \mathrm{~mol} / \mathrm{L} \mathrm{HNO}_{3}$ & 0.019 & 0.101 & 0.120 & N.D. & 0.023 & 0.127 & 92.7 \\
\hline $2.0 \mathrm{~mol} / \mathrm{L} \mathrm{TFA}$ & 0.009 & 0.114 & 0.123 & N.D. & 0.021 & 0.125 & 91.2 \\
\hline
\end{tabular}

Data are means of duplicate analyses.

N.D.: Not detected.

1) The As concentration of each extract solution was measured by ICP-MS only after dilution with 0.1 mol/L nitric acid solution.

2) Extraction efficiency (\%) was calculated as the ratio of extracted As content to the total As content. The total As concentration was determined to be $0.137 \pm 0.005 \mathrm{mg} / \mathrm{kg}$ dry weight $(n=5)$. 
Table 1-2. Effect of extraction time on extraction efficiency

\begin{tabular}{ccccccrr}
\hline \hline \multirow{2}{*}{$\begin{array}{c}\text { Extraction time } \\
(\mathrm{min})\end{array}$} & \multicolumn{4}{c}{ Concentration $(\mathrm{mg} / \mathrm{kg}$ dry weight) } & \multicolumn{2}{c}{$\begin{array}{c}\text { Extraction } \\
(\%)\end{array}$} \\
\cline { 2 - 6 } & $\mathrm{As}(\mathrm{V})$ & $\mathrm{As}(\mathrm{III})$ & $\mathrm{iAs}(\mathrm{As}(\mathrm{V})+\mathrm{As}(\mathrm{III}))$ & $\mathrm{MMA}$ & $\mathrm{DMA}$ & Extract total As $^{1)}$ & \\
\hline 0.5 & 0.015 & 0.174 & 0.189 & N.D. & 0.016 & 0.215 & 91.1 \\
1 & 0.031 & 0.177 & 0.208 & N.D. & 0.018 & 0.235 & 99.6 \\
2 & 0.032 & 0.189 & 0.221 & N.D. & 0.019 & 0.239 & 91.3 \\
4 & 0.030 & 0.182 & 0.212 & N.D. & 0.018 & 0.234 & 99.2 \\
6 & 0.043 & 0.177 & 0.220 & N.D. & 0.018 & 0.232 & 98.3 \\
8 & 0.049 & 0.157 & 0.206 & N.D. & 0.017 & 0.226 & 95.8 \\
\hline
\end{tabular}

Data are means of duplicate analyses.

N.D.: Not detected.

1) The As concentration of each extract solution was measured by ICP-MS only after dilution with 0.1 mol/L nitric acid solution.

2) Extraction efficiency was calculated as the ratio of extracted As content to the total As content. The total As concentration was determined to be $0.236 \pm 0.004 \mathrm{mg} / \mathrm{kg}$ dry weight $(n=5)$.

iAs (as As(V) or As(III)) was quantified by using a linear calibration plot $(r=0.9998)$ that was established by using standard iAs solutions having As concentrations of $0.5,1,5,10$, and $20 \mathrm{ng} / \mathrm{mL}$.

The LOD and LOQ were set at 3 times and 10 times, respectively, the standard deviation (S.D.) of the value obtained from 10 replicate analyses. The analyses were performed on a rice sample whose iAs concentration was determined to be $0.0435 \pm 0.0008 \mathrm{mg} / \mathrm{kg}$ dry weight (mean \pm S.D. $(n=10)$ ). The LOD and LOQ values of iAs were $0.0024 \mathrm{mg} / \mathrm{kg}$ dry weight and $0.0079 \mathrm{mg}$ / $\mathrm{kg}$ dry weight, respectively.

Accuracy was evaluated by calculating recovery in five replicate analyses. The recovery studies were performed by spiking $0.01 \mathrm{mg} / \mathrm{kg}$ dry weight as the LOQ level and $0.08 \mathrm{mg} / \mathrm{kg}$ dry weight as twice the iAs concentration of an un-spiked rice sample (iAs: 0.0435 \pm $0.00079 \mathrm{mg} / \mathrm{kg}$ dry weight, MMA: not detected, DMA: not detected). Either $\mathrm{As}(\mathrm{V})$ or $\mathrm{As}(\mathrm{III})$ was added to the sample. Since the JECFA set the PTWI of As as the value of iAs, the sum of iAs (V) and iAs(III) recovered is given in Table 2. Recovery of iAs at $0.01 \mathrm{mg} / \mathrm{kg}$ and $0.08 \mathrm{mg} / \mathrm{kg}$ dry weight ranged from $82.2 \%$ to $106.1 \%$. Although a slightly low recovery rate was observed in the spiking at the LOQ level, recovery in the spiking at
Table 2. Recovery of As species from finely powdered brown rice samples

\begin{tabular}{cccr}
\hline \hline Spiked species & $\begin{array}{c}\text { Spiked level } \\
(\mathrm{mg} / \mathrm{kg} \text { dry weight })\end{array}$ & $n$ & \multicolumn{1}{c}{$\begin{array}{c}\text { Recovery } \\
(\%)^{1)}\end{array}$} \\
\hline As(V) & 0.01 & 5 & $96.7 \pm 6.3^{2)}$ \\
As(III) & 0.08 & 5 & $102.4 \pm 3.1^{2)}$ \\
& 0.01 & 5 & $82.2 \pm 7.6^{2)}$ \\
MMA & 0.08 & 5 & $106.1 \pm 1.3^{2)}$ \\
& 0.01 & 5 & $92.9 \pm 1.7$ \\
DMA & 0.08 & 5 & $92.3 \pm 9.0$ \\
& 0.01 & 5 & $101.5 \pm 3.8$ \\
& 0.08 & 5 & $100.2 \pm 1.2$ \\
\hline
\end{tabular}

1) Percent recovery studies were performed on a rice sample (iAs, $0.0435 \pm 0.0008 \mathrm{mg} / \mathrm{kg}$ dry weight).

2) Recovery as total iAs was given.

the sample level was satisfactory. Recovery studies for MMA and DMA were also performed by spiking 0.01 $\mathrm{mg} / \mathrm{kg}$ and $0.08 \mathrm{mg} / \mathrm{kg}$ dry weight. The recovery of MMA and DMA was $92.3 \%$ to $101.5 \%$. The method was also applied to polished rice. When iAs was added to polished rice at the final concentration of $0.22 \mathrm{mg} / \mathrm{kg}$ dry weight, the recovery of iAs ranged from $101 \%$ to 105\% (data not shown), suggesting that the method can be applied to both brown rice and polished rice.

Precision was evaluated by calculating the coefficient

Table 3. The concentrations of iAs, MMA, DMA, and total As and the ratio of iAs content to the total As content

\begin{tabular}{|c|c|c|c|c|c|c|c|}
\hline \multirow{2}{*}{ Sample } & \multicolumn{6}{|c|}{ Concentration (mg/kg dry weight) } & \multirow{2}{*}{$\frac{\%}{\text { iAs/Total As }}$} \\
\hline & $\operatorname{As}(\mathrm{V})$ & As(III) & $\mathrm{iAs}(\mathrm{As}(\mathrm{V})+\mathrm{As}(\mathrm{III}))$ & MMA & DMA & Total As & \\
\hline 1 & N.D. & 0.146 & 0.146 & N.D. & 0.015 & 0.169 & 86.6 \\
\hline 2 & N.D. & 0.162 & 0.162 & N.D. & 0.082 & 0.260 & 62.2 \\
\hline 3 & N.D. & 0.108 & 0.108 & N.D. & 0.011 & 0.118 & 91.5 \\
\hline 4 & 0.010 & 0.171 & 0.176 & N.D. & 0.054 & 0.222 & 79.2 \\
\hline 5 & N.D. & 0.199 & 0.199 & N.D. & 0.022 & 0.247 & 80.6 \\
\hline 6 & N.D. & 0.114 & 0.114 & N.D. & 0.010 & 0.125 & 90.8 \\
\hline 7 & N.D. & 0.117 & 0.117 & N.D. & N.D. & 0.122 & 96.3 \\
\hline 8 & 0.012 & 0.221 & 0.227 & N.D. & 0.042 & 0.252 & 89.9 \\
\hline 9 & 0.010 & 0.210 & 0.215 & N.D. & 0.012 & 0.229 & 93.9 \\
\hline 10 & N.D. & 0.174 & 0.174 & N.D. & 0.022 & 0.199 & 87.4 \\
\hline
\end{tabular}

Data are means of duplicate analyses.

N.D.: Not detected. 
of variation $(\mathrm{CV})$ based on ten replicate analyses of a sample whose total As concentration was determined to be $0.04 \mathrm{mg} / \mathrm{kg}$ dry weight. Since the CV obtained was $1.8 \%$, reproducibility was also good.

The above results demonstrated that the method is efficient both in terms of accuracy and precision.

\section{Application to brown rice samples}

The method was applied to ten commercial brown rice samples. The measured concentrations of iAs, MMA, DMA, and total As are given in Table 3. The concentrations of iAs detected were in the range from 0.108 to $0.227 \mathrm{mg} / \mathrm{kg}$ dry weight. DMA was also detected in most samples. Total As concentrations were in the range from 0.118 to $0.260 \mathrm{mg} / \mathrm{kg}$ dry weight. iAs as a percentage of total As was 62.2-96.3\%. Thus, iAs was the principal As species in the short-grain brown rice samples.

\section{Acknowledgments}

This work was supported in part by a grant from the Ministry of Health, Labour and Welfare of Japan.

\section{References}

1) Gallagher, P. A., Murray, S., Wei, X., Schwegel, C. A. Creed, J. T. An evaluation of sample dispersion media used with accelerated solvent extraction for the extraction and recovery of arsenicals from LFB and DORM-2. J. Anal. At. Spectrom., 17, 581-586 (2002).

2) Soros, C., Bodo, E. T., Fodor, P., Morabito, R. The potential of arsenic speciation in molluscs for environmental monitoring. Anal. Bioanal. Chem., 377, 25-31 (2003).

3) Ackley, K. L., B'Hymer, C., Sutton, K. L., Caruso, J. A. Speciation of arsenic in fish tissue using microwaveassisted extraction followed by HPLC-ICP-MS. J. Anal. At. Spectrom., 14, 845-850 (1999).

4) Shiomi, K. "Arsenic in marine organisms, chemical forms and toxicological aspects". Arsenic in the Environment, part II: Human Health and Ecosystem Effects. Nriagu, J. O., ed. New York, USA, John Wiley \& Sons, 1994, p. 261-282. (ISBN 0471304360)

5) Shiomi, K. The chemical form, toxicity, and metabolism of the arsenicals in marine seaweed. Shokuhin Eiseigaku Zasshi (J. Food Hyg. Soc. Japan), 33, 1-10 (1992).

6) Maitani, T., Nagaoka, M. H. "Toxic metals". Food evaluation and prevention technology for food safety. Ito, T., Kawamoto, S., Sugiyama, J., Nishijima, M., Maitani, T., eds. Tokyo, Japan, CMC Publishing Co., Ltd., 2006, p. 229240. (ISBN 4882315548)

7) Pizarro, I., Gómez, M., Cámara, C., Palacios, M. A. Arsenic speciation in environmental and biological samples: Extraction and stability studies. Anal. Chim. Acta, 495, 8598 (2003).

8) Williams, P. N., Price, A. H., Raab, A., Hossain, S. A., Feldmann, J., Meharg, A. A. Variation in arsenic speciation and concentration in paddy rice related to dietary exposure. Environ. Sci. Technol., 39, 5531-5540 (2005).

9) McSheehy, S., Szpunar, J., Morabito, R., Quevauviller, P. The speciation of arsenic in biological tissues and the certification of reference materials for quality control. Trends Anal. Chem., 22, 191-209 (2003).

10) Heitkemper, D. T., Vela, N.P., Stewart, K. R., Westphal, C. S. Determination of total and speciated arsenic in rice by ion chromatography and inductively coupled plasma mass spectrometry. J. Anal. At. Spectrom., 16, 299-306 (2001).

11) Yost, L. J., Schoof, R. A., Aucoin R. Intake of inorganic arsenic in the North American diet. Hum. Ecol. Risk Assess., 4, 137-152 (1998).

12) Schoof, R. A., Yost, L. J., Eickoff, J., Crescelius, E. A., Cragin, D. W., Meacher, D. M., Menzel, D. B. A Market basket survey of inorganic arsenic in food. Food Chem. Toxicol., 37, 839-846 (1999).

13) Kohlmeyer, U., Jantzen, E., Kuballa, J., Jakubik, S. Benefits of high resolution IC-ICP-MS for the routine analysis of inorganic and organic arsenic species in food products of marine and terrestrial origin. Anal. Bioanal. Chem., 377, 6-13 (2003).

14) Pizarro, I., Gomez, M., Palacios, M. A., Camara, C. Evaluation of stability of arsenic species in rice. Anal. Bioanal. Chem., 376, 102-109 (2003).

15) D'Amato, M, Forte, G., Caroli, S. Identification and quantification of major species of arsenic in rice. J. AOAC Int., 87, 238-243 (2004).

16) McKiernan, J. W., Creed, J. T., Brockhoff, C. A., Caruso, J. A., Lorenzana, R. M. A comparison of automated and traditional methods for the extraction of arsenicals from fish. J. Anal. At. Spectrom., 14, 607-613 (1999).

17) Buldini, P. L., Cavalli, S., Trifirò, A. State-of-the-art ion chromatographic determination of inorganic ions in food. J. Chromatogr. A, 789, 529-548 (1997).

18) Sanz. E., Muñoz-Olivas, R., Cámara, C. A rapid and novel alternative to conventional sample treatment for arsenic speciation in rice using enzymatic ultrasonic probe. Anal. Chim. Acta, 535, 227-235 (2005).

19) Francesconi, K. A., Kuehnelt, D. Determination of As species: a critical review of methods and applications, 2000-2003. Analyst, 129, 373-395 (2004).

20) Nagaoka, M. H., Hanaoka, K., Usui, M., Nishimura, T., Maitani, T. Nitric acid-based partial-digestion method for selective determination of inorganic arsenic in hijiki and application to soaked hijiki. Shokuhin Eiseigaku Zasshi (J. Food Hyg. Soc. Japan), 49, 88-94 (2008). 